\title{
Disturbance and recolonisation by small reef fishes: the role of local movement versus recruitment
}

\author{
C. D. Lefèvre, D. R. Bellwood* \\ Australian Research Council Centre of Excellence for Coral Reef Studies, \\ and College of Marine and Environmental Sciences, James Cook University, Townsville, Queensland 4811, Australia
}

\begin{abstract}
An understanding of the responses of fish assemblages to disturbance events is central to the ongoing management of coral reef habitats. To understand the factors shaping patterns of recovery, we examined the recolonisation of populations of small cryptic fishes following experimental removal. After removing resident cryptobenthic reef fish assemblages from otherwise undisturbed coral rubble areas we observed a rapid recovery. Within $8 \mathrm{wk}$, fish assemblages were similar to their pre-removal structure in terms of fish abundance, species diversity and species richness. However, species differed in the speed and nature of their return. The return of larger species (e.g. Parapercis cylindrica) was largely mediated by recolonisation, while smaller, less mobile species (e.g. Eviota spp. and Enneapterygius spp.) relied primarily on recruitment, presumably from the plankton. Although patterns of settlement and recruitment are ultimately responsible for replenishment of local populations, our data suggest that mobility may play a strong role in restoring fish assemblages in the short term. These results have significant implications for our understanding of the response of coral reef ecosystems to disturbance events and highlight the importance of selecting appropriate criteria for evaluating reef resilience. If these short-lived fish species are a model for their longer-lived counterparts, it suggests that local responses to disturbance will depend largely on the mobility of species. Identifying both the recruitment and movement abilities of species will be critical in understanding the ability of fish assemblages to recover after disturbance.
\end{abstract}

KEY WORDS: Coral reefs · Cryptobenthic reef fish · Assemblage · Habitat disturbance Postsettlement movement $\cdot$ Resilience $\cdot$ Size at settlement

\section{INTRODUCTION}

A recent recognition of the spatial and temporal heterogeneity in the structure and dynamics of ecological communities has led to a greater focus on the role of disturbance in shaping community structure and persistence (Halford et al. 2004, Pratchett et al. 2008, Wilson et al. 2009). On coral reefs, fish communities often display marked variability in community structure at small spatial and temporal scales (Halford et al. 2004, Wilson et al. 2006). However, an understanding of community responses to disturbance is central to the ongoing management of coral reef habitats when facing increasing anthropogenic disturbances (Wilson et al. 2006, Adam et al. 2014).

The capacity for coral reef fish communities to recover or regenerate following natural and/or anthropogenic disturbances is governed by the interplay of several physical and biological factors. Biological factors include the extent of variability in the community, the availability of colonists, the lifehistory characteristics of dominant species (including recruitment strategies and propensity of species to disperse; Niemi et al. 1990, Coker et al. 2012a) and the functional attributes of species (Bellwood et al. 2004, 2012a). Reports of the effects of disturbances on coral reef fish assemblages have been variable; several studies have observed minimal impacts on 
the species richness of assemblages (e.g. Syms \& Jones 2000, Planes et al. 2005, Bellwood et al. 2006, Emslie et al. 2008), while other studies have reported distinct declines in species richness (e.g. Halford et al. 2004, Graham et al. 2006). This disparity in the results implies that disturbance events do not necessarily cause a change in species richness, but other variables may be more sensitive, such as sizefrequency distributions (Graham et al. 2006) or community composition (Bellwood et al. 2006, 2012b, Pratchett et al. 2008). The response of fishes to disturbance, therefore, appears to be species specific rather than community wide (Coker et al. 2012a).

Intuitively, species mobility would appear to be a primary determinant of colonisation and recovery of fish assemblages. On coral reefs, the spatial extent and frequency of movement observed in reef fishes varies broadly, from species that move hundreds of kilometres (e.g. serranids; Hutchinson \& Rhodes $2010)$ to species that rarely move more than a metre (e.g. gobies; Depczynski \& Bellwood 2004, Nash et al. 2015). Nonetheless, it is uncertain whether interspecific differences in mobility can account for differences in observed colonisation and recovery rates. Using cryptobenthic reef fish assemblages as a model, we examined the recovery rates of small reef fish species. Due to their extremely limited postsettlement mobility (home ranges of $<1 \mathrm{~m}^{2}$; Depczynski \& Bellwood 2004, 2005a), strong associations with the benthos (Munday \& Jones 1998, Depczynski \& Bellwood 2004, Munday 2004, González-Cabello \& Bellwood 2009, Ahmadia et al. 2012b) and exceptional sensitivity to changes in habitat structure (Bellwood et al. 2006, Pratchett et al. 2008), cryptobenthic reef fishes may be useful models for exploring interspecific patterns of colonisation and recovery. Because small cryptic fish have extreme life histories, geared towards rapid growth and fast turnover (Hernaman \& Munday 2005, Depczynski \& Bellwood 2006, Winterbottom et al. 2011), we would expect these fishes to be exceptionally responsive to change and exhibit substantial interspecific variation in colonisation and recovery rates following a localized disturbance event.

The aim of the present study, therefore, was to document the nature and extent of recovery after disturbance in cryptobenthic reef fish assemblages inhabiting coral rubble habitats. Spe- cifically, we investigated the role of local movement versus recruitment in shaping post-disturbance assemblages.

\section{MATERIALS AND METHODS}

The study was conducted between August and November 2009 at Lizard Island in the northern Great Barrier Reef (GBR) (14 $\left.{ }^{\circ} 40^{\prime} \mathrm{S}, 145^{\circ} 27^{\prime} \mathrm{E}\right)$. Two sites were censused between Bird and South Islands at depths of 2 to $3 \mathrm{~m}$ (Fig. 1). These 2 sites were chosen based on their similar aspect and habitat characteristics, i.e. a back reef with coral rubble conglomerate composed of $>70 \%$ hard coral rubble. The coral rubble consisted of fragments of dead branching corals (mainly Acropora spp.) of 2 to $15 \mathrm{~cm}$ in length and 0.5 to $1.5 \mathrm{~cm}$ in diameter.

\section{Experimental design}

To assess the recolonisation rates of small cryptic reef fishes, we initially sampled rubble areas at the 2 sites ( $\mathrm{n}=25$ sample areas per site; $\mathrm{n}=50$ sample areas in total), removing all fish present from each $1 \mathrm{~m}^{2}$ sample area. The sample area, relative to the magnitude of the home ranges of the fish species involved, simulated a removal event that, in larger fish, would approximate a single charge in dynamite fishing or localized fishing such as fish corrals, seine nets, or fish traps. The sample areas were each

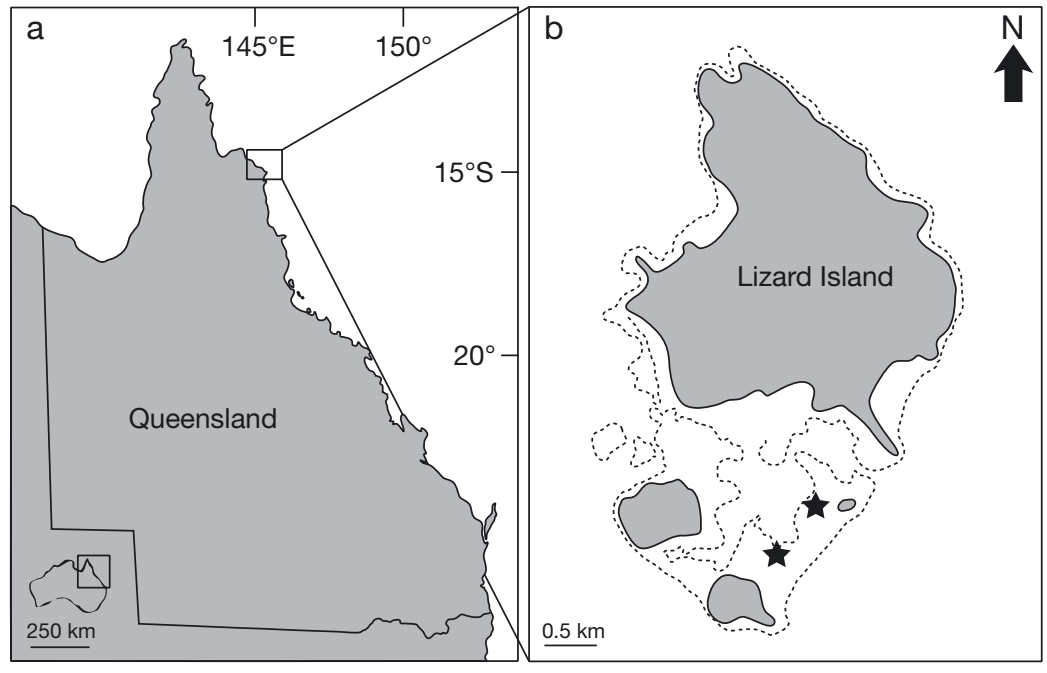

Fig. 1. Location of study sites: (a) geographical location of Lizard Island in the northern Great Barrier Reef and (b) Lizard Island. Dashed line indicates the reef crest of the fringing reef; stars represent the 2 study sites. Map adapted from Kramer et al. (2014b) 
resampled once, at one of 5 time intervals: $5 \mathrm{~h}, 24 \mathrm{~h}$, $1 \mathrm{wk}, 2 \mathrm{wk}$, or $8 \mathrm{wk}$ after manipulation. From each site a total of 5 replicates were obtained per time interval. The areas censused were clearly marked with coloured tags to ensure resampling of the exact same area. Initial sample areas were chosen haphazardly and sampled within a $1 \mathrm{wk}$ period during the Austral cool season, several months before the summer peak recruitment period. Care was taken not to disturb the physical habitat structure of the rubble areas or the biotic components living in these rubble areas. The spacing between sample areas was at least $10 \mathrm{~m}$. Each sample area was surrounded by rubble so movement of more mobile fish species would not be impeded. Larger mobile reef fishes (e.g. acanthurids or labrids) were not sampled using this methodology and were not included in the analyses.

\section{Collecting techniques}

Cryptobenthic reef fishes were collected while scuba diving using enclosed clove-oil stations (following Ackerman \& Bellwood 2002; see Robertson \& Smith-Vaniz 2010). A weighted fine-mesh (2 mm) net covering a basal area of $1 \mathrm{~m}^{2}$ was used to prevent fish from escaping. A 5:1 ethanol:clove oil solution (anaesthetic) was then pumped into the netted area, and, after $1 \mathrm{~min}, 2$ divers began a 10 min systematic search for anaesthetised fish to remove all fish present from the $1 \mathrm{~m}^{2}$ area. Specimens found in crevices and holes were carefully dislodged using forceps. Anaesthetised fishes were placed in labelled plastic bags and immersed in an ice-water slurry.

Specimens were identified to species level, measured to the nearest $0.1 \mathrm{~mm}$ (total length) and stored in $80 \%$ ethanol. Several specimens of the genus Eviota were identified by D. W. Greenfield (University of Hawai'i) and H. K. Larson (Museum and Art Gallery of the Northern Territory).

\section{Statistical analyses}

Changes to the cryptobenthic reef fish assemblages after experimental disturbance were evaluated using 3 different metrics: total abundance, species richness and species diversity (Shannon-Wiener diversity index, $H^{\prime}$ ). These are commonly utilised metrics for evaluating changes in reef assemblages following disturbance (e.g. Halford et al. 2004, Bellwood et al. 2006). Differences among sites and time intervals were analysed using 2-way analysis of vari- ance (ANOVAs) with site and time interval being treated as fixed factors. To account for variability among sample areas, all values (abundance, species richness and diversity) were calculated as the difference between the initial and resampling period for a specific sample area (e.g. $t_{(5 \mathrm{~h})}=t_{\text {initial }(5 \mathrm{~h})}-t_{\text {recovery }(5 \mathrm{~h}) \text {, }}$ and $\left.t_{(24 \mathrm{~h})}=t_{\text {initial }(24 \mathrm{~h})}-t_{\text {recovery }(24 \mathrm{~h})}\right)$. By comparing the exact same sample over time, the metric of assemblage change was the extent of the return to each sample area's specific initial condition. Total abundance, species richness and diversity were $\log _{(x+1)}$ transformed to meet the assumptions of normality and homoscedasticity. Following a significant result, homogenous groupings were identified using Tukey's honestly significant difference (HSD) post hoc comparison tests. The analyses of fish assemblages between time intervals in terms of fish abundance, species richness and diversity detected no significant effect of site (Table 1); therefore, data were pooled across the 2 sites for presentation.

Additionally, changes in community composition were investigated using a non-metric multidimensional scaling analysis (nMDS) (based on a BrayCurtis similarity matrix) of the mean number of individuals per species per site (for each time treatment). Multiple correlations were carried out to determine the magnitude of the contribution of individual species to the observed groupings (performed in Primer

Table 1. Results of 2-way ANOVAs comparing the fish assemblage structures amongst sites and time intervals in terms of abundance, species richness and species diversity (Shannon-Wiener diversity index, $H^{\prime}$ ). Variables are expressed in terms of the mean number or diversity of fishes within post-removal replicate samples compared to the pre-removal samples ( $\mathrm{n}=10$ samples per time interval). ${ }^{*} p$-values in bold denote significant differences $(p<0.05)$

\begin{tabular}{|lrrrc|}
\hline Source of variation & df & MS & $F$ & $\mathrm{p}$ \\
\hline Abundance & & & & \\
Time interval & 4 & 2.021 & 82.246 & $\mathbf{0 . 0 0 1}^{*}$ \\
Site & 1 & 0.197 & 0.803 & 0.376 \\
Time interval $\times$ Site & 4 & 0.014 & 0.585 & 0.676 \\
Error & 40 & 0.024 & & \\
Species richness & & & & \\
Time interval & 4 & 1.113 & 33.026 & $\mathbf{0 . 0 0 1}^{*}$ \\
Site & 1 & 0.009 & 0.283 & 0.597 \\
Time interval $\times$ Site & 4 & 0.010 & 0.095 & 0.983 \\
Error & 40 & 0.034 & & \\
Species diversity $\left(\boldsymbol{H}^{\prime}\right)$ & & & & \\
Time interval & 4 & 0.002 & 7.003 & $\mathbf{0 . 0 0 1}$ \\
Site & 1 & 0.000 & 0.600 & 0.443 \\
Time interval $\times$ Site & 4 & 0.000 & 1.314 & 0.281 \\
Error & 40 & & & \\
\hline
\end{tabular}


6.0). Data were $\log (x+1)$ transformed prior to analyses to improve multivariate normality and homoscedasticity. Any grouping of data in the nMDS of assemblages between initial and recovery samples was determined using an analysis of similarity (ANOSIM; based on a Bray-Curtis similarity matrix of $\log (x+1)$ transformed data).

Multivariate analysis of variance tests (MANOVA) were used to further compare species abundance between pre- and post-disturbance fish assemblages. Analyses were based on the 16 most abundant species (with $>15$ ind. in total; see Table 4). Abundance data were $\log (x+1)$ transformed to satisfy requirements for multivariate normality and homoscedasticity. Bonferroni-corrected multiple comparisons tests were used to identify the time intervals in which abundance varied significantly for each species. Differences in size (length in $\mathrm{cm}$ ) of 6 species were investigated among pre- and post-disturbance samples using 1-way ANOVAs followed by Tukey's HSD post hoc tests to identify where differences lay. These 6 species were selected as they were particularly abundant and provided a clear representation of the alternate patterns.

\section{RESULTS}

\section{Changes in fish abundance and species richness}

Fish removal exerted significant effects on fish abundance, species richness and diversity (Fig. 2, Tables 1 \& 2). In the time immediately following the disturbance (after $5 \mathrm{~h}$ ), fish assemblages were dramatically altered with a mean $( \pm \mathrm{SE})$ of $17.3 \pm 2.6$ ind. $\mathrm{m}^{-2}$ fewer individuals than prior to the disturbance (Fig. 2a). Fish abundance recovered slightly a week after the disturbance, but it was not until 2 wk following manipulation that abundances approached the values found in initial samples (Fig. 2a). Species rich-

Table 2. Mean number of individuals and species sampled for each time interval for both initial and recovery periods (mean $\pm \mathrm{SE} ; \mathrm{n}=10$ samples per treatment). Note that all means are based on $1 \mathrm{~m}^{2}$ sample areas

\begin{tabular}{|lrrrr|}
\hline \multirow{2}{*}{ Treatment } & \multicolumn{2}{c}{ No. of ind. $\mathrm{m}^{-2}$} & \multicolumn{2}{c|}{ No. of species $\mathrm{m}^{-2}$} \\
& Initial & Recovery & Initial & Recovery \\
\hline $5 \mathrm{~h}$ & $23.0 \pm 1.1$ & $5.7 \pm 0.8$ & $10.8 \pm 0.8$ & $4.5 \pm 0.7$ \\
$24 \mathrm{~h}$ & $21.0 \pm 1.6$ & $6.8 \pm 0.7$ & $9.4 \pm 0.6$ & $3.4 \pm 0.2$ \\
$1 \mathrm{wk}$ & $20.3 \pm 1.3$ & $11.4 \pm 1.0$ & $13.0 \pm 0.7$ & $6.8 \pm 0.6$ \\
$2 \mathrm{wk}$ & $19.1 \pm 0.7$ & $16.9 \pm 0.7$ & $11.8 \pm 0.6$ & $11.0 \pm 0.5$ \\
$8 \mathrm{wk}$ & $18.4 \pm 1.8$ & $19.8 \pm 1.3$ & $11.7 \pm 0.7$ & $11.5 \pm 0.6$ \\
\hline
\end{tabular}

ness was consistently lower in early post-disturbance samples relative to the pre-disturbance samples (Fig. 2b). One week after fish removal, overall species richness was, on average, $6.2 \pm 0.9$ species $\mathrm{m}^{-2}$ lower than initial undisturbed rubble areas. A return to pre-disturbance species richness was not noted until Weeks 2 to 8 (Table 3). Likewise, the Shannon-
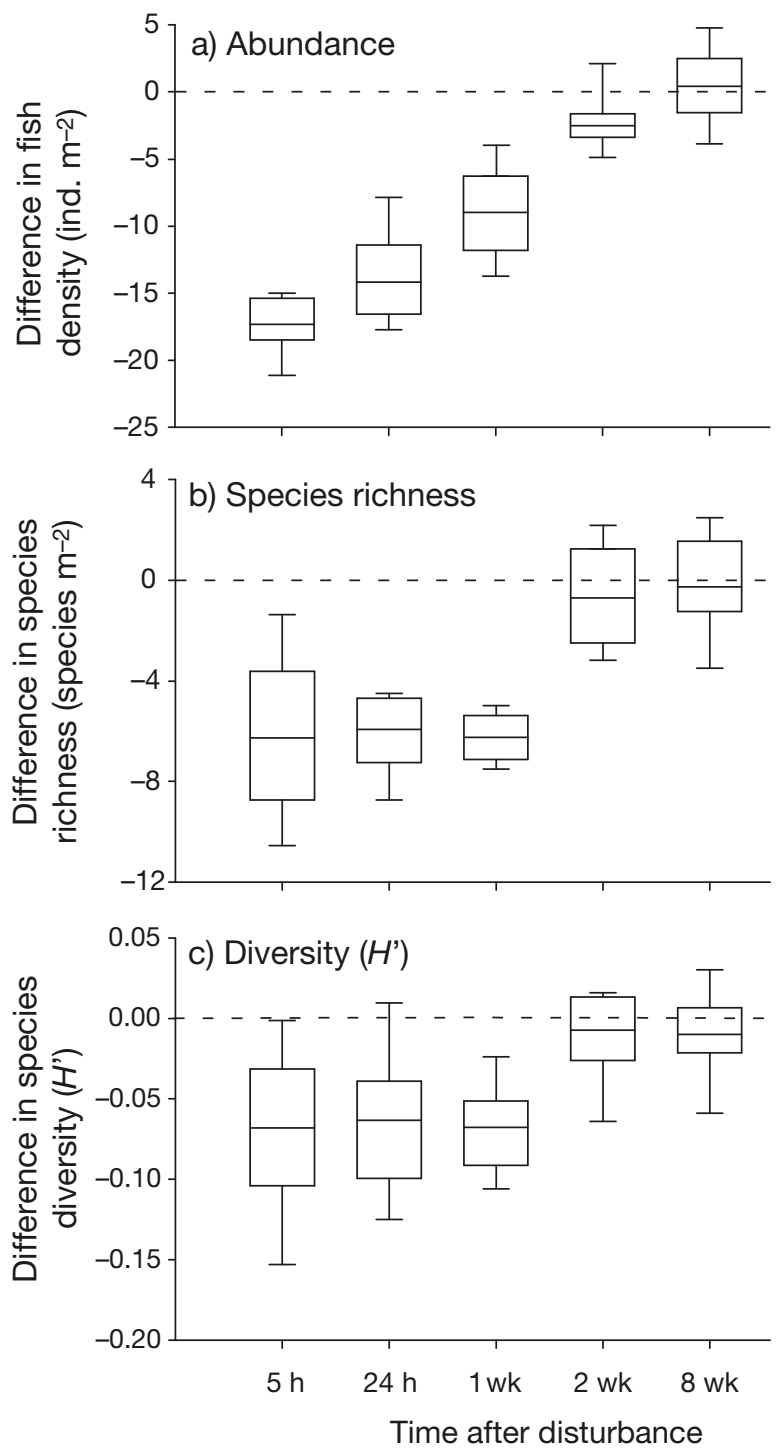

Fig. 2. Box and whisker plots of (a) abundance, (b) species richness and (c) species diversity (Shannon-Wiener diversity index, $H^{\prime}$ ) in the community composition of cryptobenthic fishes for each time interval after disturbance. Variables are expressed in terms of the number or diversity of fishes within post-removal replicate samples compared to the preremoval samples ( $n=10$ samples per time interval). The dashed line (at difference ' 0 ') represents the pre-removal sample condition. The boxplot contains $50 \%$ of the data points, and the middle line of the box is the median. The ends of the projecting error bars show minimum and maximum values 
Table 3. Summary of Tukey's HSD post hoc tests identifying the time intervals that statistically differ from each other in terms of abundance, species richness and species diversity (Shannon-Wiener diversity index, $H^{\prime}$ ). Variables are expressed in terms of the mean number or diversity of fishes within post-removal replicate samples compared to the preremoval samples (mean $\pm \mathrm{SE}_{;} \mathrm{n}=10$ samples per time interval). ${ }^{*} p$-values in bold denote significant differences $(\mathrm{p}<0.05)$

\begin{tabular}{|lclll|}
\hline & $5 \mathrm{~h}$ & $24 \mathrm{~h}$ & $1 \mathrm{wk}$ & $2 \mathrm{wk}$ \\
\hline Abundance & & & & \\
$5 \mathrm{~h}$ & & & & \\
$24 \mathrm{~h}$ & 0.070 & & & \\
$1 \mathrm{wk}$ & $\mathbf{0 . 0 0 1}^{*}$ & $\mathbf{0 . 0 0 1}^{*}$ & & \\
$2 \mathrm{wk}$ & $\mathbf{0 . 0 0 1}^{*}$ & $\mathbf{0 . 0 0 1}^{*}$ & $\mathbf{0 . 0 0 1}^{*}$ & \\
$8 \mathrm{wk}$ & $\mathbf{0 . 0 0 1}^{*}$ & $\mathbf{0 . 0 0 1}^{*}$ & $\mathbf{0 . 0 0 1}{ }^{*}$ & 0.187 \\
Species richness & & & \\
$5 \mathrm{~h}$ & & & & \\
$24 \mathrm{~h}$ & 0.994 & & & \\
$1 \mathrm{wk}$ & 0.999 & 0.997 & & \\
$2 \mathrm{wk}$ & $\mathbf{0 . 0 0 1}^{*}$ & $\mathbf{0 . 0 0 1}^{*}$ & $\mathbf{0 . 0 0 1}^{*}$ & \\
$8 \mathrm{wk}$ & $\mathbf{0 . 0 0 1}^{*}$ & $\mathbf{0 . 0 0 1}^{*}$ & $\mathbf{0 . 0 0 1}$ & 0.986 \\
Species diversity (H') & & & \\
$5 \mathrm{~h}$ & & & & \\
$24 \mathrm{~h}$ & 0.998 & & & \\
$1 \mathrm{wk}$ & 1.000 & 0.998 & & \\
$2 \mathrm{wk}$ & $\mathbf{0 . 0 1 0}^{*}$ & $\mathbf{0 . 0 2 2}^{*}$ & $\mathbf{0 . 0 1 1}^{*}$ & \\
$8 \mathrm{wk}$ & $\mathbf{0 . 0 0 9}^{*}$ & $\mathbf{0 . 0 2 0}^{*}$ & $\mathbf{0 . 0 1 0}^{*}$ & 1.000 \\
\hline
\end{tabular}

Wiener diversity index $\left(H^{\prime}\right)$ was significantly reduced shortly after fish removal (Fig. 2c), with no evidence of recovery towards the original composition until Weeks 2 to 8 .

\section{Changes in community structure}

The nMDS revealed 3 distinct clusters of fish assemblages: pre-disturbance, early post-disturbance ( 5 to $24 \mathrm{~h}, 1 \mathrm{wk}$ ) and late post-disturbance ( 2 to $8 \mathrm{wk}$ ) (Fig. 3; ANOSIM: Global $\mathrm{R}=0.94, \mathrm{p}=0.0001$ ). Compositional changes were primarily driven by different relative abundances of particular species rather than losses (Fig. 3). The pre-removal assemblage structure was characterised by the abundance of a variety of species from 6 different families, including several species of pygmy gobies (Eviota queenslandica, Eviota variola and Eviota cf. zonura), 2 triplefins (Enneapterygius atrogulare and Enneapterygius tutuilae), the goby Callogobius sclateri and the longfin Plesiops coeruleolineatus. One week following disturbance, the assemblages were still distinct from pre-removal assemblages, although a slight recovery in total fish abundance was apparent (Fig. 2, Table 2). This disparity indicates that sites were re-

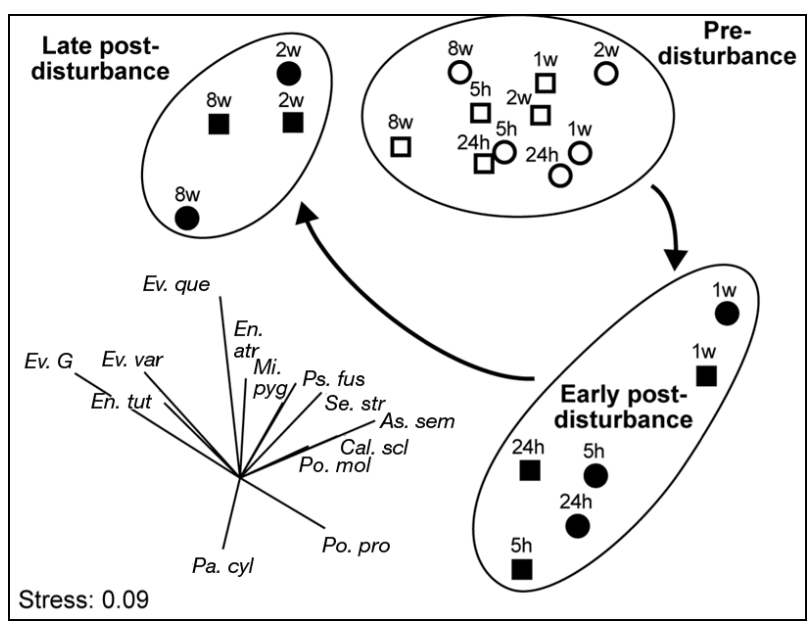

Fig. 3. Two-dimensional plot of a non-metric multidimensional scaling analysis of the variation of cryptobenthic reef fish assemblages between initial and recovery samples. Each time interval after disturbance includes initial and recovery samples (open and closed symbols, respectively) for both sites (squares: Site 1; circles: Site 2). The contribution of abundant species ( $\mathrm{n}>15$ ind. in total) is displayed in vectors. Species codes represent the first 2 letters of the genus and 3 letters of the species names (see full species names in Table 4)

colonised relatively quickly, but not by the same species as those originally present. Indeed, early postdisturbance samples were distinguished by the relative abundance of 2 damselfishes (Pomacentrus chrysurus and Pomacentrus sp.), the sandperch Parapercis cylindrica and the goby Asterropteryx semipunctata. This compositional difference did not persist through time, and fish assemblage structure eventually became almost indistinguishable from pre-disturbed samples, with most species recolonising the rubble areas after 8 wk (Fig. 3). Notable exceptions include the goby Callogobius sclateri, the longfin Plesiops coeruleolineatus and the scorpionfish Sebastapistes strongia, which underwent severe declines in abundance after disturbance and were still almost completely absent from post-disturbance samples after $8 \mathrm{wk}$.

\section{Species-specific responses during recovery}

Recolonisation success after disturbance varied among species. Indeed, MANOVAs based on the 16 most abundant species revealed significant differences in species assemblages between pre- and post-disturbance samples (Tables 4 \& 5). Post hoc 
Table 4. Families, species and numbers of individuals sampled from each of the 2 sites $(\mathrm{n}=50$ per location) and summed overall $(\mathrm{n}=100)$, and their contribution (in $\%$ ) to the total species pool. The 16 most abundant species (with $>15$ ind. in total) were chosen for further analyses (displayed in bold). These 16 species represent $88.8 \%$ of the total species pool

\begin{tabular}{|c|c|c|c|c|c|}
\hline Family & Species & Site 1 & Site 2 & Total & $\begin{array}{l}\text { Percent } \\
\text { of total }\end{array}$ \\
\hline Gobiidae & Eviota queenslandica & 123 & 124 & 247 & 21.82 \\
\hline Pseudochromidae & Pseudochromis fuscus & 64 & 46 & 110 & 9.72 \\
\hline Gobiidae & Eviota variola & 35 & 53 & 88 & $\mathbf{7 . 7 7}$ \\
\hline Pinguipedidae & Parapercis cylindrica & 51 & 34 & 85 & 7.51 \\
\hline Gobiidae & Eviota cf. zonura & 50 & 31 & 81 & 7.16 \\
\hline Gobiidae & Istigobius goldmanni & 35 & 28 & 63 & 5.57 \\
\hline Gobiidae & Asterropteryx semipunctata & 24 & 38 & 62 & 5.48 \\
\hline Tripterygiidae & Enneapterygius tutuilae & 31 & 19 & 50 & 4.42 \\
\hline Pomacentridae & Pomacentrus sp. & 33 & 17 & 50 & 4.42 \\
\hline Pomacentridae & Pomacentrus chrysurus & 30 & 10 & 40 & 3.53 \\
\hline Tripterygiidae & Enneapterygius atrogulare & 27 & 11 & 38 & 3.36 \\
\hline Gobiidae & Callogobius sclateri & 10 & 17 & 27 & 2.39 \\
\hline Plesiopidae & Plesiops coeruleolineatus & 6 & 11 & 17 & 1.50 \\
\hline Syngnathidae & Micrognathus pygmaeus & 7 & 9 & 16 & 1.41 \\
\hline Blenniidae & Salarias fasciatus & 10 & 6 & 16 & 1.41 \\
\hline Scorpaenidae & Sebastapistes strongia & 6 & 9 & 15 & 1.33 \\
\hline Pomacentridae & Pomacentrus moluccensis & 6 & 6 & 12 & 1.06 \\
\hline Pseudochromidae & Pseudochromis cyanotaenia & 6 & 4 & 10 & 0.88 \\
\hline Gobiidae & Amblygobius phalaena & 2 & 7 & 9 & 0.80 \\
\hline Gobiidae & Eviota punctulata & 1 & 8 & 9 & 0.80 \\
\hline Pomacentridae & Pomacentrus wardi & 1 & 8 & 9 & 0.80 \\
\hline Pomacentridae & Pomacentrus philippinus & 4 & 3 & 7 & 0.62 \\
\hline Gobiidae & Eviota albolineata & 3 & 3 & 6 & 0.53 \\
\hline Pomacentridae & Pomacentrus amboinensis & 1 & 3 & 4 & 0.35 \\
\hline Syngnathidae & Choeroichthys brachysoma & 1 & 2 & 3 & 0.27 \\
\hline Pseudochromidae & Cypho purpurascens & 0 & 3 & 3 & 0.27 \\
\hline Pomacentridae & $\begin{array}{l}\text { Dischistodus } \\
\text { pseudochrysopoecilus }\end{array}$ & 2 & 1 & 3 & 0.27 \\
\hline Gobiidae & Eviota sp. D & 1 & 2 & 3 & 0.27 \\
\hline Gobiidae & Fusigobius duospilus & 0 & 3 & 3 & 0.27 \\
\hline Blenniidae & Salarias alboguttatus & 2 & 1 & 3 & 0.27 \\
\hline Blenniidae & Salarias guttatus & 2 & 1 & 3 & 0.27 \\
\hline Gobiidae & Callogobius hasseltii & 0 & 2 & 2 & 0.18 \\
\hline Gobiidae & Eviota sp. T & 0 & 2 & 2 & 0.18 \\
\hline Gobiesocinae & Discotrema crinophila & 1 & 1 & 2 & 0.18 \\
\hline Gobiidae & Eviota afelei & 0 & 2 & 2 & 0.18 \\
\hline Gobiidae & Eviota prasites & 0 & 2 & 2 & 0.18 \\
\hline Gobiidae & Eviota sp. Y & 1 & 1 & 2 & 0.18 \\
\hline Apogonidae & Fowleria vaiulae & 1 & 1 & 2 & 0.18 \\
\hline Apogonidae & Fowleria variegata & 0 & 2 & 2 & 0.18 \\
\hline Gobiidae & Fusigobius neophytus & 2 & 0 & 2 & 0.18 \\
\hline Muraenidae & Gymnothorax chilospilus & 1 & 1 & 2 & 0.18 \\
\hline Opistognathidae & Opistognathus sp. & 0 & 2 & 2 & 0.18 \\
\hline Pomacentridae & Pomacentrus adelus & 1 & 1 & 2 & 0.18 \\
\hline Pseudochromidae & Pseudochromis flammicauda & 0 & 2 & 2 & 0.18 \\
\hline Apogonidae & Apogon novemfasciatus & 0 & 1 & 1 & 0.09 \\
\hline Blenniidae & Crossosalarias macrospilus & 0 & 1 & 1 & 0.09 \\
\hline Blenniidae & Ecsenius stictus & 1 & 0 & 1 & 0.09 \\
\hline Tripterygiidae & Enneapterygius cf. tutuilae & 1 & 0 & 1 & 0.09 \\
\hline Gobiidae & Eviota infulata & 0 & 1 & 1 & 0.09 \\
\hline Gobiidae & Eviota sp. L & 1 & 0 & 1 & 0.09 \\
\hline Gobiidae & Luposicya lupus & 0 & 1 & 1 & 0.09 \\
\hline Pinguipedidae & Parapercis lineopunctata & 1 & 0 & 1 & 0.09 \\
\hline Gobiidae & Pleurosicya sp. & 1 & 0 & 1 & 0.09 \\
\hline Pomacentridae & Pomacentrus bankanensis & 0 & 1 & 1 & 0.09 \\
\hline Pomacentridae & Pomacentrus sp. B & 0 & 1 & 1 & 0.09 \\
\hline Blenniidae & Salarias cf. ceramensis & 0 & 1 & 1 & 0.09 \\
\hline Callionymidae & Synchiropus sp. & 1 & 0 & 1 & 0.09 \\
\hline Tripterygiidae & Ucla cf. xenogrammus & 0 & 1 & 1 & 0.09 \\
\hline \multicolumn{6}{|l|}{ Totals } \\
\hline 15 families & 58 species & 581 & 551 & 1132 & $100 \%$ \\
\hline
\end{tabular}

Bonferroni-corrected multiple comparisons indicated that species abundances varied among time intervals in 10 out of 16 species (Table 5). However, there were very consistent patterns within genera. At one extreme, several damselfish species, blennies (including Salarias fasciatus), the sandperch Parapercis cylindrica and the goby Asterropteryx semipunctata showed no difference in abundance between time intervals, while cryptic fish species with small adults $(<2 \mathrm{~cm})$ from the families Gobiidae (Eviota spp.) and Tripterygiidae (Enneapterygius spp.) were particularly slow in recolonising. Recolonising individuals from the genera Eviota and Enneapterygius were on average $1.0 \pm 0.2 \mathrm{~cm}$ and $0.8 \pm 0.4 \mathrm{~cm}$ smaller (mean $\pm \mathrm{SE}$ ), respectively, than in the initial samples (Fig. 4). Indeed, sizefrequency distributions of Eviota spp. and Enneapterygius spp. at the study site indicate that these individuals recolonised the rubble areas as recently settled fish, with minimum total lengths smaller than recorded by previous studies (Fig. 5; NB local species in these 2 genera have a maximum total length of $2.5 \mathrm{~cm}$ and $2.7 \mathrm{~cm}$, respectively). In contrast, larger species such as Parapercis cylindrica and Asterropteryx semipunctata showed no significant variation in mean total length throughout the recolonisation period, suggesting that these species had moved as larger individuals from neighbouring areas (Fig. 4).

\section{DISCUSSION}

Disturbance is an important process driving the dynamics of benthic marine communities, including coral reefs. However, to date, little attention has been paid to the relative importance of recolonisation versus recruitment during recovery, especially in highly mobile taxa such as coral reef fishes. Our data suggest 
Table 5. Results of the MANOVA probability values and Bonferroni-corrected comparison tests identifying the species that differed significantly in abundance among time intervals. Analyses were based on the 16 most abundant species censused (with $>15$ ind. in total) using $\log (x+1)$ transformed data. Letters indicate homogenous groups (same letter) or significant $(\mathrm{p}<0.05)$ statistical differences (different letter) of each species among time intervals

\begin{tabular}{|c|c|c|c|c|c|c|c|}
\hline \multirow[t]{2}{*}{ Family } & \multirow[t]{2}{*}{ Species } & \multicolumn{5}{|c|}{$\longrightarrow$ Time interval $\longrightarrow$} & \multirow[t]{2}{*}{$\mathrm{p}$} \\
\hline & & $5 \mathrm{~h}$ & $24 \mathrm{~h}$ & $1 \mathrm{wk}$ & $2 \mathrm{wk}$ & $8 \mathrm{wk}$ & \\
\hline \multirow[t]{6}{*}{ Gobiidae } & Asterropteryx semipunctata & $\mathrm{A}$ & $\mathrm{AB}$ & $\mathrm{AB}$ & $\mathrm{AB}$ & B & 0.025 \\
\hline & Callogobius sclateri & A & $\mathrm{B}$ & B & B & B & 0.004 \\
\hline & Eviota queenslandica & $\mathrm{A}$ & $\mathrm{A}$ & $\mathrm{A}$ & A & B & $<0.001$ \\
\hline & Eviota cf. zonura & A & A & A & A & B & $<0.001$ \\
\hline & Eviota variola & A & $\mathrm{A}$ & A & $\mathrm{A}$ & B & $<0.001$ \\
\hline & Istigobius goldmanni & A & $\mathrm{A}$ & A & $\mathrm{A}$ & $\mathrm{A}$ & 0.067 \\
\hline \multirow{2}{*}{$\begin{array}{l}\text { Triptery- } \\
\text { giidae }\end{array}$} & Enneapterygius atrogulare & $\mathrm{A}$ & $\mathrm{A}$ & $\mathrm{A}$ & $\mathrm{AB}$ & B & 0.037 \\
\hline & Enneapterygius tutuilae & A & A & A & $\mathrm{AB}$ & B & 0.011 \\
\hline $\begin{array}{l}\text { Syngna- } \\
\text { thidae }\end{array}$ & Micrognathus pygmaeus & $\mathrm{A}$ & $\mathrm{A}$ & $\mathrm{A}$ & $\mathrm{A}$ & B & $<0.001$ \\
\hline $\begin{array}{l}\text { Pingui- } \\
\text { pedidae }\end{array}$ & Parapercis cylindrica & A & $\mathrm{A}$ & A & A & A & 0.180 \\
\hline Plesiopidae & Plesiops coeruleolineatus & $\mathrm{A}$ & $\mathrm{AB}$ & $\mathrm{AB}$ & B & $\mathrm{AB}$ & 0.027 \\
\hline \multirow{2}{*}{$\begin{array}{l}\text { Poma- } \\
\text { centridae }\end{array}$} & Pomacentrus chrysurus & $\mathrm{A}$ & A & A & $\mathrm{A}$ & A & 0.727 \\
\hline & Pomacentrus sp. & A & $\mathrm{A}$ & $\mathrm{A}$ & $\mathrm{A}$ & $\mathrm{A}$ & 0.362 \\
\hline $\begin{array}{l}\text { Pseudo- } \\
\text { chromidae }\end{array}$ & Pseudochromis fuscus & A & A & A & $\mathrm{A}$ & B & 0.023 \\
\hline Blenniidae & Salarias fasciatus & $\mathrm{A}$ & $\mathrm{A}$ & $\mathrm{A}$ & $\mathrm{A}$ & $\mathrm{A}$ & 0.389 \\
\hline $\begin{array}{l}\text { Scorpae- } \\
\text { nidae }\end{array}$ & Sebastapistes strongia & A & A & A & $\mathrm{AB}$ & B & 0.011 \\
\hline
\end{tabular}

the original species composition may take much longer. The difference between changes in abundance and composition is instructive and reveals the different roles of recruitment versus local movement.

Responses of cryptobenthic reef fishes to the vacant rubble areas took one of 2 forms: (1) post-settlement movement of adults and juveniles from neighbouring rubble areas and/or (2) larval settlement from the plankton. Given the large patches of rubble available, there was ample opportunity for fishes to move from adjacent areas. It is therefore no surprise that local movements were the primary recolonisation mechanism for adult damselfishes and sandperches, which moved to vacant areas shortly after disturbance. These findings support the observations of Coker et al. (2012b) who found that adult damselfishes showed strong abilities to move to alternative areas follow- that mobility underpins the variation in reef fish assemblages after habitat disturbance and reveal the potential of reef fishes to ameliorate local disturbance through both recolonisation and recruitment.

\section{Responses to disturbance at a community level}

Fish removal resulted in significant differences in cryptobenthic reef fish assemblages. However, recolonisation and settlement redressed these differences after just $8 \mathrm{wk}$. Several other studies have documented the remarkable resilience of fish communities after being severely affected by direct disturbances. Planes et al. (2005) for example, reported that fish assemblages displayed a similar community structure within 5 yr of nuclear tests in French Polynesia. On a much smaller scale, Syms \& Jones (2000) observed a rapid recovery $(<3 \mathrm{mo})$ of fish assemblages on the GBR, following experimental removal of resident fishes from patch reefs.

Our results likewise indicate that recolonisation rates of fish assemblages may be relatively rapid. However, the initial appearance of recovery might be deceiving. While numbers return quickly, a return to ing coral loss. However, in the present study, recolonisation of adults and juveniles did not completely remove the disturbance effects. Although recolonisation of the rubble areas resulted in a total fish abundance that was almost indistinguishable from initial samples after just $2 \mathrm{wk}$, the recolonised rubble areas had compositional differences, which remained until the recruitment of small cryptic fish occurred. Indeed, larval settlement from the water column appeared to be important for several taxa (especially Eviota spp.) that seemed to be reluctant to move between rubble areas to recolonise the vacant rubble space, even in contiguous rubble patches. The extent of natural mobility of fishes appears to have been largely responsible for these observed patterns, and seems to have been operating at extremely small scales ( $<1$ to $1.5 \mathrm{~m}^{2}$ ). It is this lack of movement that shapes assemblage composition during recovery. Small cryptic fishes did not appear to respond to available space. This suggests that postsettlement processes, such as recolonisation, are not able to fill depopulated areas and that, for some taxa, recruitment is critical.

The difference between moving and recruiting species appears to reflect home range size. The Gob- 
Fig. 4. Mean total length of individuals $(\mathrm{cm}, \pm \mathrm{SE} ; \mathrm{n}=10$ samples per time interval) for initial and recovery samples of (a) Asterropteryx semipunctata, (b) Parapercis cylindrica, (c) Eviota queenslandica, (d) Eviota cf. zonura, (e) Pseudochromis fuscus and (f) Enneapterygius tutuilae. Letters denote statistically indistinguishable groupings (same letter). The first 2 species recover by local movement; the remaining 4 species depend on recruitment. The dashed line represents the approximate size at settlement (in $\mathrm{cm}$; following Privitera 2002, Walker \& McCormick 2004, Depczynski \& Bellwood 2006, Longenecker \& Langston 2005; cf. Fig. 5). The scale bar under each fish represents $1 \mathrm{~cm}$

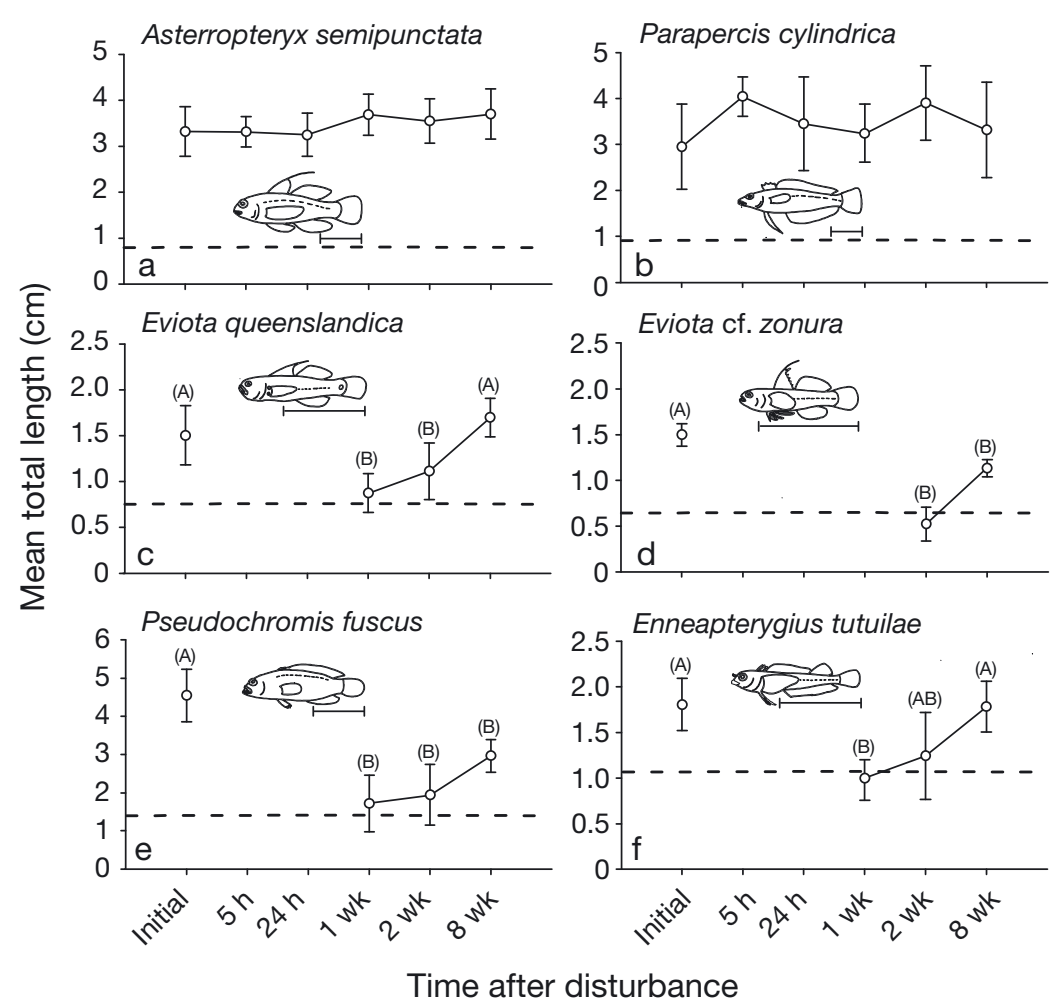

location (Stewart \& Jones 2001). Most predators have visual systems that rely on movement to detect potential prey (Coker et al. 2009); thus, predators are more likely to perceive and strike at prey fishes that are moving between vacant habitat spaces. With background mortality rates for gobies at 7 to $8 \% \mathrm{~d}^{-1}$ (Depczynski \& Bellwood 2006), any increase is likely to be unviable. Consequently, it appears that small home ranges and site fidelity in small gobies are important attributes that reduce both the risk of predation and the extent to which gobies can colonise new habitats. This illustrates the importance of life-history traits in shaping patterns of recovery. In comparison, larger, more mobile fishes that have lower mortality and inherently larger home ranges, as a result of body size (Nash et al. 2015), are expected to increase the probability of individuals successfully moving or expanding their home ranges. For these larger species, the risks of movement between habitats may therefore be outweighed by the potential benefits of successfully moving to a new vacant habitat space. However, strong site attachment appears to be similar in some larger reef fishes which display relatively small home ranges and iidae comprise a high number of species that have very restricted home ranges $\left(<1 \mathrm{~m}^{2}\right.$; Depczynski \& Bellwood 2004) and therefore spend most of their adult life within the confines of a small rubble area or a single live coral colony (Munday et al. 2001, Depczynski \& Bellwood 2004, González-Cabello \& Bellwood 2009, Ahmadia et al. 2012a, Tornabene et al. 2013). Consequently, these small cryptic fishes are highly dependent on this specific habitat for shelter, food resources and reproduction (Munday 2002). Furthermore, the extremely limited mobility of most gobies (Depczynski \& Bellwood 2004), coupled with increased predation risk during movement (Stewart \& Jones 2001) and strong interspecific competition for suitable habitat (Munday 2004), may reduce any potential benefit of moving to a vacant habitat and may explain why these small fishes exhibit limited movement.

Restricted movement in small fishes may be related to high susceptibility to predation during their re- strong site fidelity (reviewed by Nash et al. 2015). The patterns seen in the cryptobenthic fishes may thus be an accurate model for their larger counterparts, despite the potential mobility of larger fishes. The distinction between recolonisation and recruitment may not be restricted to cryptobenthic species.

\section{Implications for coral reef monitoring}

Disturbance events on coral reefs alter not only the structure of fish assemblages, but also have the potential to alter parts of the reef framework, including living and dead corals (Wilson et al. 2006), which are likely to influence the movement and recruitment patterns of species utilising non-living coral substrata (Jones \& Syms 1998). 'Coral rubble' as defined herein is a very consistent and extremely common component of coral reefs, and represents a widespread habitat on the GBR (Wismer et al. 2009). Rubble has been 

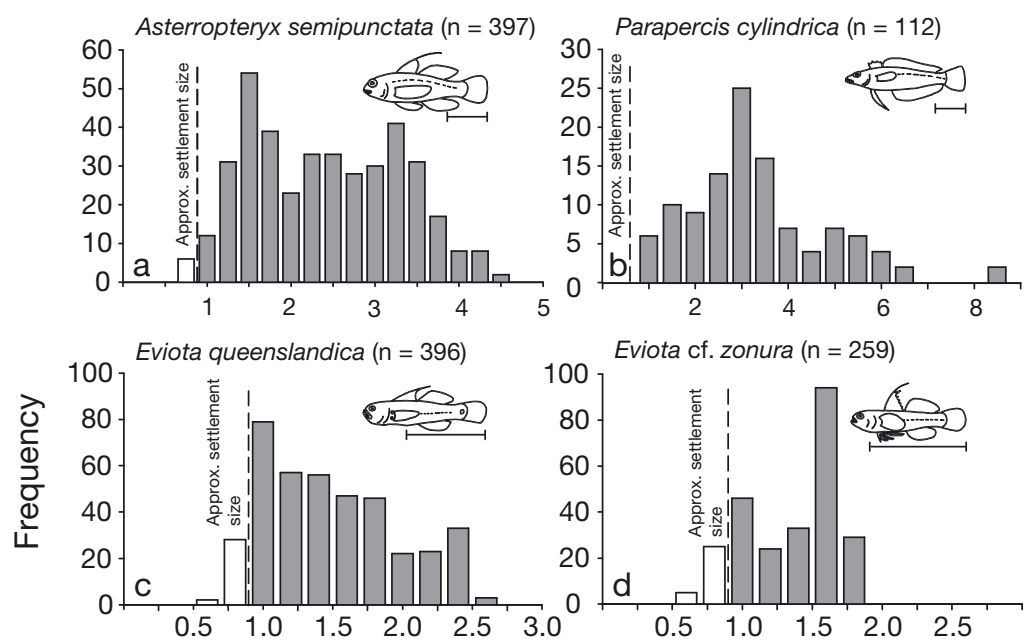

Eviota cf. zonura $(\mathrm{n}=259)$
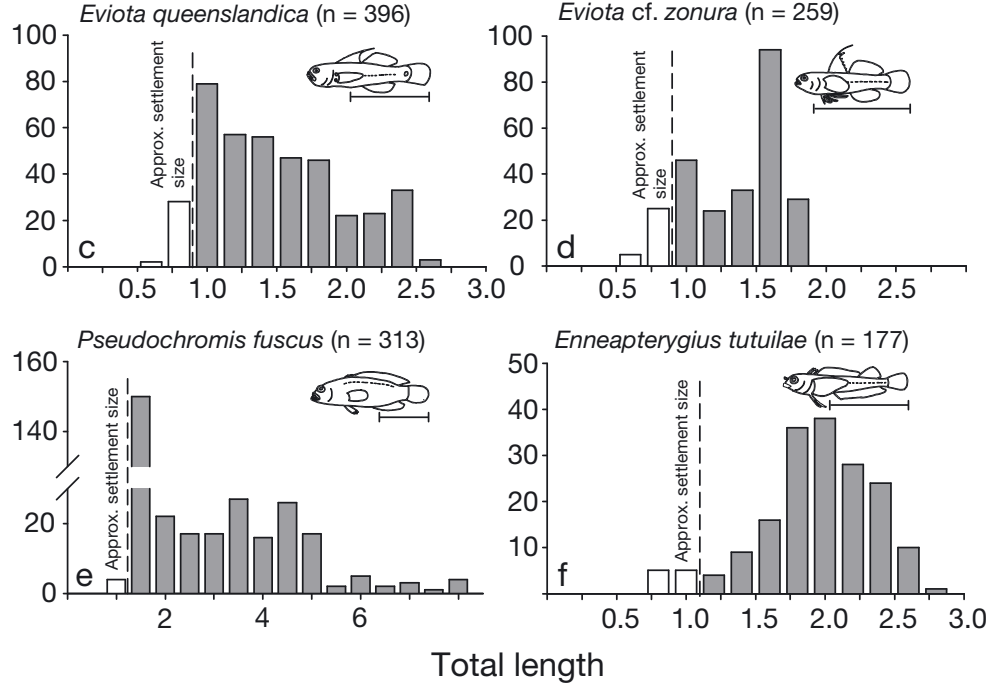

Fig. 5. Frequency distribution of total length of individuals (in $\mathrm{cm}$ ) of (a) Asterropteryx semipunctata, (b) Parapercis cylindrica, (c) Eviota queenslandica, (d) Eviota cf. zonura, (e) Pseudochromis fuscus and (f) Enneapterygius tutuilae. All specimens were collected from the study site. The dashed line represents the approximate size at settlement (in $\mathrm{cm}$ ) based on published data and observations of relatively unpigmented (i.e. recently settled) individuals (Privitera 2002, Walker \& McCormick 2004, Longenecker \& Langston 2005, Depczynski \& Bellwood 2006, C. Lefèvre unpubl. data). The scale bar under each fish represents $1 \mathrm{~cm}$

recognised as an important habitat in supporting reef productivity and represents a key habitat for small and cryptic fishes (Depczynski \& Bellwood 2003, Depczynski et al. 2007, Kramer et al. 2014a).

The need for sensitive metrics for evaluating coral reef degradation is of utmost importance, and presents an ongoing challenge in reef management. Rubble-based cryptobenthic reef fish assemblages, and in particular the gobiid component, may represent a valuable alternative metric for measuring coral reef condition. These sensitive taxa may be particularly useful indicators of environmental health, as they provide us with a high level of resolution to detect changes between habitats, at any scale ranging from several metres to biogeographic regions (Depczynski \& Bellwood 2004, 2005a, González-Cabello \& Bellwood 2009, Bellwood et al. 2006, 2012b). Cryptobenthic fish density is likely to increase in a degraded coral reef system, as rubble habitats support the highest densities of small fishes (Ahmadia et al. 2012a). Beyond benefiting from their ability to repeatedly recolonise new niches on the reef, and particularly coral rubble habitats (Tornabene et al. 2013), small cryptic fishes are extremely responsive to changes due to their exceptional lifehistory features (cf. Bellwood et al. 2006).

Small cryptic fishes have exceptionally short lifespans, with maximum longevities spanning from several weeks (shortest known vertebrate lifespan of $59 \mathrm{~d}$; Depczynski \& Bellwood 2005b) to just over 1 yr (Hernaman \& Munday 2005, Depczynski \& Bellwood 2006, Winterbottom \& Southcott 2008). As a key foundation of ecosystem processes, small fish assemblages display extremely high turnover rates (with up to 7 generations per year; Depczynski \& Bellwood 2006), a desirable property for a bio-indicator of coral reef condition (Winterbottom et al. 2011). Indeed, negative effects on reefs can be observed rapidly and may provide an early warning of changes in other reef components (Bellwood et al. 2012b). Understanding the mechanisms that underpin recolonisation will be crucial to our ability to use these small taxa as indicators of reef condition, and will enable us to take management initiatives in order to prevent further reef degradation (Smith-Vaniz et al. 2006).

\section{Ecological implications}

There is increasing evidence that the alteration of habitats as a result of both anthropogenic and natural disturbances may have profound effects on the structure of coral reef fish assemblages (Wilson et al. 2006, 2009, Bellwood et al. 2012b, Pratchett et al. 2012, Coker et al. 2014). In the present study we observed differences in total abundance, species richness and in the size structure of small reef fish assemblages during post-disturbance recovery. These differences are largely explained by the limited post-settlement mobility of numerous small cryptic fishes.

Although processes such as settlement and recolonisation are ultimately responsible for replenishment 
of local populations, our data suggest that mobility can play a strong role in restoring fish assemblages in the short term and that the specific effects of habitat disturbance on fish communities will depend on the taxonomic and functional composition of the associated fish assemblage. Our results have broad implications for our understanding of the response of coral reef ecosystems to disturbance, and highlight the importance of selecting appropriate criteria for evaluating reef resilience. Identifying both the recruitment and movement abilities of fishes is critical to understanding the potential for regeneration after disturbance. If these short-lived species are a model for their longer-lived counterparts, our data suggest that the response of fish assemblages to local disturbance may take a number of years to manifest itself and that the pattern of recovery depends critically on the movement ability of specific reef fish taxa.

Acknowledgements. We thank the staff of Lizard Island Research Station for field support: C. Goatley, A. GonzálezCabello and J. Tanner for field assistance; M. Casey for statistical advice; D. Greenfield and H. Larson for taxonomic identifications; C. Goatley, A. González-Cabello, J. Tanner, J. Welsh and 3 anonymous reviewers for helpful discussions or comments on earlier drafts of the manuscript. This project was supported by the Australian Research Council (D.R.B.).

\section{LITERATURE CITED}

Ackerman JL, Bellwood DR (2002) Comparative efficiency of clove oil and rotenone for sampling tropical reef fish assemblages. J Fish Biol 60:893-901

Adam TC, Brooks AJ, Holbrook SJ, Schmitt RJ, Washburn L, Bernardi G (2014) How will coral reef fish communities respond to climate-driven disturbances? Insight from landscape-scale perturbations. Oecologia 176:285-296

> Ahmadia GN, Pezold FL, Smith DJ (2012a) Cryptobenthic fish biodiversity and microhabitat use in healthy and degraded coral reefs in SE Sulawesi, Indonesia. Mar Biodivers 42:433-442

Ahmadia GN, Sheard LJ, Pezold FL, Smith DJ (2012b) Cryptobenthic fish assemblages across the coral reefseagrass continuum in SE Sulawesi, Indonesia. Aquat Biol 16:125-135

$>$ Bellwood DR, Hughes TP, Folke C, Nystrom M (2004) Confronting the coral reef crisis. Nature 429:827-833

Bellwood DR, Hoey AS, Ackerman JL, Depczynski M (2006) Coral bleaching, reef fish community phase shifts and the resilience of coral reefs. Glob Change Biol 12:1587-1594

Bellwood DR, Hoey AS, Hughes TP (2012a) Human activity selectively impacts the ecosystem roles of parrotfishes on coral reefs. Proc R Soc B 279:1621-1629

Bellwood DR, Baird AH, Depczynski M, González-Cabello A, Hoey AS, Lefèvre CD, Tanner JK (2012b) Coral recovery may not herald the return of fishes on damaged coral reefs. Oecologia 170:567-573

> Coker DJ, Pratchett MS, Munday PL (2009) Coral bleaching and habitat degradation increase susceptibility to predation for coral-dwelling fishes. Behav Ecol 20:1204-1210
Coker DJ, Graham NAJ, Pratchett MS (2012a) Interactive effects of live coral and structural complexity on the recruitment of reef fishes. Coral Reefs 31:919-927

> Coker DJ, Pratchett MS, Munday PL (2012b) Influence of coral bleaching, coral mortality and conspecific aggression on movement and distribution of coral-dwelling fish. J Exp Mar Biol Ecol 414-415:62-68

> Coker DJ, Wilson SK, Pratchett MS (2014) Importance of live coral habitat for reef fishes. Rev Fish Biol Fish 24:89-126

> Depczynski M, Bellwood DR (2003) The role of cryptobenthic reef fishes in coral reef trophodynamics. Mar Ecol Prog Ser 256:183-191

> Depczynski M, Bellwood DR (2004) Microhabitat utilisation patterns in cryptobenthic coral reef fish communities. Mar Biol 145:455-463

Depczynski M, Bellwood DR (2005a) Wave energy and spatial variability in community structure of small cryptic coral reef fishes. Mar Ecol Prog Ser 303:283-293

> Depczynski M, Bellwood DR (2005b) Shortest recorded vertebrate lifespan found in a coral reef fish. Curr Biol 15: R288-R289

> Depczynski M, Bellwood DR (2006) Extremes, plasticity, and invariance in vertebrate life history traits: insights from coral reef fishes. Ecology 87:3119-3127

> Depczynski M, Fulton CJ, Marnane MJ, Bellwood DR (2007) Life history patterns shape energy allocation among fishes on coral reefs. Oecologia 153:111-120

- Emslie MJ, Cheal AJ, Sweatman H, Delean S (2008) Recovery from disturbance of coral and reef fish communities on the Great Barrier Reef, Australia. Mar Ecol Prog Ser 371:177-190

> González-Cabello A, Bellwood DR (2009) Local ecological impacts of regional biodiversity on reef fish assemblages. J Biogeogr 36:1129-1137

> Graham NAJ, Wilson SK, Jennings S, Polunin NVC, Bijoux JP, Robinson J (2006) Dynamic fragility of oceanic coral reef ecosystems. Proc Natl Acad Sci USA 103:8425-8429

> Halford AR, Cheal AJ, Ryan D, Williams DM (2004) Resilience to large-scale disturbance in coral and fish assemblages on the Great Barrier Reef. Ecology 85:1892-1905

Hernaman V, Munday PL (2005) Life-history characteristics of coral reef gobies. I. Growth and life-span. Mar Ecol Prog Ser 290:207-221

Hutchinson N, Rhodes K (2010) Home range estimates for squaretail coralgrouper, Plectropomus areolatus (Ruppell, 1830). Coral Reefs 29:511-519

Jones GP, Syms C (1998) Disturbance, habitat structure and the ecology of fishes on coral reefs. Aust J Ecol 23:287-297

Kramer MJ, Bellwood DR, Bellwood O (2014a) Benthic Crustacea on coral reefs: a quantitative survey. Mar Ecol Prog Ser 511:105-116

- Kramer MJ, Bellwood DR, Bellwood O (2014b) Large-scale spatial variation in epilithic algal matrix cryptofaunal assemblages on the Great Barrier Reef. Mar Biol 161: 2183-2190

> Longenecker K, Langston R (2005) Life history of the Hawaiian blackhead triplefin, Enneapterygius atriceps (Blennioidei, Tripterygiidae). Environ Biol Fishes 73: 243-251

> Munday PL (2002) Does habitat availability determine geographical-scale abundances of coral-dwelling fishes? Coral Reefs 21:105-116

Munday PL (2004) Habitat loss, resource specialization, and extinction on coral reefs. Glob Change Biol 10: 1642-1647 
Munday PL, Jones GP (1998) The ecological implications of small body size among coral-reef fishes. Oceanogr Mar Biol Annu Rev 36:373-411

Munday PL, Jones GP, Caley MJ (2001) Interspecific competition and coexistence in a guild of coral-dwelling fishes. Ecology 82:2177-2189

Nash KL, Welsh JQ, Graham NA, Bellwood DR (2015) Home-range allometry in coral reef fishes: comparison to other vertebrates, methodological issues and management implications. Oecologia 177:73-83

Niemi GJ, Devore P, Detenbeck N, Taylor D and others (1990) Overview of case-studies on recovery of aquatic systems from disturbance. Environ Manage 14:571-587

Planes S, Galzin R, Bablet JP, Sale PF (2005) Stability of coral reef fish assemblages impacted by nuclear tests. Ecology 86:2578-2585

Pratchett MS, Munday PL, Wilson SK, Graham NAJ and others (2008) Effects of climate-induced coral bleaching on coral-reef fishes: ecological and economic consequences. Oceanogr Mar Biol Annu Rev 46:251-296

Pratchett MS, Coker DJ, Jones GP, Munday PL (2012) Specialization in habitat use by coral reef damselfishes and their susceptibility to habitat loss. Ecol Evol 2: 2168-2180

Privitera LA (2002) Reproductive biology of the coral-reef goby, Asterropteryx semipunctata, in Kaneohe Bay, Hawaii. Environ Biol Fishes 65:289-310

Robertson DR, Smith-Vaniz WF (2010) Use of clove oil in collecting coral reef fishes for research. Mar Ecol Prog Ser 401:295-302

Smith-Vaniz WF, Jelks HL, Rocha LA (2006) Relevance of cryptic fishes in biodiversity assessments: a case study at Buck Island Reef National Monument, St. Croix. Bull Mar Sci 79:17-48

Editorial responsibility: Charles Birkeland, Honolulu, Hawaii, USA
Stewart BD, Jones GP (2001) Associations between the abundance of piscivorous fishes and their prey on coral reefs: implications for prey-fish mortality. Mar Biol 138: 383-397

Syms C, Jones GP (2000) Disturbance, habitat structure, and the dynamics of a coral-reef fish community. Ecology 81: $2714-2729$

Tornabene L, Ahmadia GN, Berumen ML, Smith DJ, Jompa J, Pezold FL (2013) Evolution of microhabitat association and morphology in a diverse group of cryptobenthic coral reef fishes (Teleostei: Gobiidae: Eviota). Mol Phylogenet Evol 66:391-400

Walker SPW, McCormick MI (2004) Otolith-check formation and accelerated growth associated with sex change in an annual protogynous tropical fish. Mar Ecol Prog Ser 266: 201-212

Wilson SK, Graham NAJ, Pratchett MS, Jones GP, Polunin NVC (2006) Multiple disturbances and the global degradation of coral reefs: Are reef fishes at risk or resilient? Glob Change Biol 12:2220-2234

Wilson SK, Dolman AM, Cheal AJ, Emslie MJ, Pratchett MS, Sweatman HPA (2009) Maintenance of fish diversity on disturbed coral reefs. Coral Reefs 28:3-14

Winterbottom R, Southcott L (2008) Short lifespan and high mortality in the western Pacific coral reef goby Trimma nasa. Mar Ecol Prog Ser 366:203-208

> Winterbottom R, Alofs KM, Marseu A (2011) Life span, growth and mortality in the western Pacific goby Trimma benjamini, and comparisons with T. nasa. Environ Biol Fishes 91:295-301

Wismer S, Hoey AS, Bellwood DR (2009) Cross-shelf benthic community structure on the Great Barrier Reef: relationships between macroalgal cover and herbivore biomass. Mar Ecol Prog Ser 376:45-54

Submitted: April 16, 2015; Accepted: August 10, 2015 Proofs received from author(s): September 19, 2015 